International Journal of Social Science And Human Research

ISSN(print): 2644-0679, ISSN(online): 2644-0695

Volume 05 Issue 01 January 2022

DOI: 10.47191/ijsshr/v5-i1-41, Impact factor-5.586

Page No: 305-309

\title{
The Effectiveness of Cooperative Learning Jigsaw Model and Team Game Tournament (TGT) on Dribling Ability in Football Games Class XI State High School 2 Gadingrejo
}

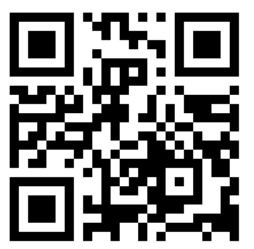

\author{
Surisman $^{1}$, Ardian Cahyadi $^{2}$ \\ ${ }^{1,2}$ Lampung State University
}

\begin{abstract}
Physical education learning process must be supported by adequate learning facilities and infrastructure, such as sports equipment and the field as a learning resource for physical education learning. If one of them is inadequate, both limited in quantity and quality, it will greatly affect the learning process, especially learning basic football techniques. Dribbling is an attempt to push the ball intermittently with the ball position not far from our feet and must be controlled by the dribbeler while running to achieve certain goals in the game of football. This study aims to determine how much influence the practice of the jigsaw cooperative learning model and the team game tournament (TGT) model on dribbling skills in the XI class football game of State High School 2 Gadingrejo. The method used in this study is a comparative experimental method, the population is 203 students, while the sample technique used is proportional random sampling of 40 students. The procedure in this study used Pretest, Treatment and Post-test. The data analyzed is data from the results of the initial and final tests. Calculating the results of the initial and final tests using the T-test data analysis technique. The results of this study are; 1) There is a significant effect of the jigsaw model of cooperative learning on the ability to dribble the ball in soccer games. 2) There is a significant effect of the TGT learning model on the ability to dribble the ball in soccer games. 3) There is a significant difference between the experimental group of Jigsaw and TGT cooperative models.
\end{abstract}

KEYWORDS: Dribbling, Cooperative Jigsaw, Football Game, TGT

\section{INTRODUCTION}

Physical education is an integral part of overall education to develop all aspects of the human person, both physically and spiritually, through physical activities to form Indonesian people (Jian Andri Kurniawan et al., 2015). Understanding Physical education is an educational process through physical activities designed to improve physical fitness, develop motor skills, knowledge and behavior of healthy and active living, sportsmanship, and emotional intelligence (Fudin \& Hariyadi, 2020). The learning environment is carefully arranged to promote the growth and development of all domains, physical, psychomotor, cognitive, and affective for each student (Avdeeva \& Tulyakova, 2018).

The benefits of physical education in schools are to develop students' talents which are educational institutions and accommodate students who are fostered so that they have the ability, intelligence and skills (Harvey et al., 2014). The educational process requires coordinated and directed coaching (Pasichnyk et al., 2021). Thus, students are expected to achieve maximum learning achievement so that educational goals can be achieved. Physical activity chosen to achieve competence in physical education is through various physical activities and sports that are selected and adapted to the objectives to be achieved, the needs, capabilities and characteristics of students. Reasonable physical activity for recreation and physical activity for sport or achievement. The selected activities are centered on physical activities that can activate large muscles, basic movements and physical movements through sports (Eryiğit \& Ay, 2021).

One of the lack of development of the physical education learning process in schools is due to the lack of creativity and innovation of physical education teachers in using learning models (Minana-Signes \& Monfort-Panego, 2021). Physical education teachers always use improvised facilities and infrastructure continuously without thinking to develop more fun and innovative learning models so that many students feel bored and bored. Many physical education teachers still use conventional learning processes so that the learning process becomes monotonous and not interesting. They are often found using the same learning methods and using the field in the school environment without trying new things by developing modified learning models (Marwan, 2019).

Football is a team game played by two teams, each team consisting of eleven players including a goalkeeper (Rafi et al., 2018). The game may be played with all parts of the body such as the legs, head, chest and arms in a passive position except with 


\section{The Effectiveness of Cooperative Learning Jigsaw Model and Team Game Tournament (TGT) on Dribling Ability in Football Games Class XI State High School 2 Gadingrejo}

both active arms (hands). Almost all games are carried out with foot skills, except for the goalkeeper in playing the free ball using his limbs, with his feet and hands. When starting to prepare for a soccer match, the main skill that first makes someone feel motivated and satisfied is the ability to dribbling. Therefore, the basic dribbling technique must be mastered by all players. Of course, this requires special exercises with various variations of learning (Ryom et al., 2020).

The goal of dribbling is to keep the ball while running across an opponent or advancing into open space. In performing the dribbling technique, it is divided into several forms of movement, based on the impact of the foot with the ball. Dribbling is an individual skill that every football player must master. Because it is very closely related to ball control in the field, because the ball must always be in our control. Dribbling must be able to be done either without an opponent or through opponents with various ball control techniques (Sugiyama et al., 2017).

Dribbling with the outside of the foot, dribbling with the outside is one way to control the ball (Hornig et al., 2016). This ball control skill is used when the player in control of the ball is running and pushing the ball so that it can keep the ball on the outside of the foot. Dribbling uses the tortoise of the foot where the shoelaces are located, a common mistake that is often made by beginners in this technique is hitting the ball not on the back of the foot but using the tip of the toe. This relates to learning the basic technique of dribbling the ball in soccer games. In the learning process with these basic techniques, the teacher is less creative, resulting in student saturation in the learning process, resulting in the learning process learning becomes tiring and boring, there is nothing challenging and new to students. The teacher has given material about football at school but in a less attractive way and the equipment used is also very few and not varied, it should be for students who have experienced the process of learning about football no longer having difficulty in dribbling the ball because they have received material from the teacher.

The game of football is also a game that is very popular with students of State High School 2 Gadingrejo. However, the student's fondness for playing football cannot be used as a guarantee that they can play football properly and correctly. The initial findings at the time of the study showed that there were some students who had not been able to master the basic techniques and the dribbling movement was still stiff, the foot hitting the ball was still wrong and the body movement for dribbling was still less flexible, then the learning given was also still using conventional methods. For example, students are only given a ball and only given orders to dribble from one point to another. With these problems, it is necessary to modify learning that is fun and attracts students' interest in learning skills in the game of football through playing. Thus the author wishes to make a study by applying a Jigsaw cooperative learning method and team game tournament into learning materials for dribbling in soccer games.

Based on the description above, the learning outcomes achieved by students cannot be separated from the teacher's role in selecting and implementing learning models that are in accordance with the characteristics of the material and students in order to achieve learning success. The learning model chosen must be able to empower students to move more to try the basic movements of football, namely dribbling and practicing repeatedly.

Based on the description above, the authors want to know how the selection of the model, whether it is appropriate and there are differences, in improving students' basic movement skills in football subjects, especially in dribbling. So the author took the title "The Influence of Jigsaw Cooperative Learning Model and Team Game Tournament (TGT) on dribbling ability in Football Game Class XI State High School 2 Gadingrejo.

\section{METHODS}

The method used in this study is a comparative experimental method, the population is 203 students, while the sample technique used is proportional random sampling of 40 students. The procedure in this study used Pre-test, Treatment and Post-test. The data analyzed is data from the results of the initial and final tests. Calculating the results of the initial and final tests using the T-test data analysis technique.

\section{RESULTS AND DISCUSSION}

\section{Data Description}

Table 1. Initial Test

\begin{tabular}{llllllll}
\hline Number & Model & $\boldsymbol{X}$ & $\mathbf{f i}$ & $\geq \boldsymbol{X}$ & $\mathbf{f i}$ & $\leq \boldsymbol{X}$ & Description \\
\hline 1. & Jigsaw & 61 & 6 & $30 \%$ & 14 & $70 \%$ & $100 \%$ \\
\hline 2. & TGT & 50 & 11 & $55 \%$ & 9 & $45 \%$ & $100 \%$ \\
\hline
\end{tabular}

Table 2. Final Test

\begin{tabular}{llllllll}
\hline Number & Model & $\boldsymbol{X}$ & $\mathbf{f i}$ & $\mathbf{X} \boldsymbol{X}$ & $\mathbf{f i}$ & $\leq \boldsymbol{X}$ & Description \\
\hline 1. & Jigsaw & 69 & 11 & $55 \%$ & 9 & $45 \%$ & $100 \%$ \\
\hline 2. & TGT & 59 & 13 & $65 \%$ & 7 & $35 \%$ & $100 \%$ \\
\hline
\end{tabular}




\section{The Effectiveness of Cooperative Learning Jigsaw Model and Team Game Tournament (TGT) on Dribling Ability in Football Games Class XI State High School 2 Gadingrejo}

From the percentage table above, it can be seen that the average number of initial tests for the jigsaw group is 61 points, while the TGT is 50 points and those who are above the class average in the initial test for the jigsaw group are 6 people out of 20 testes and if they are presented it is $30 \%$ and those who are in the middle below the average as many as 14 people with a percentage of 70\%, while for the cooperative learning model group the TGT model which is above the class average there are 11 people out of 20 testes and if the percentage is 55\% and below the class average there are 9 people of 20 testes with a percentage of $45 \%$. After being given treatment, the final test results showed an average of 69 in the jigsaw group final test results, with a percentage of 55\% above the average or 11 people from 20 testes and $45 \%$ below the average, namely 9 people from 20 testes, while the team game tournament group became 59 with 13 people from 20 testes were above the average with a percentage of $65 \%$ and there were 7 people below the class average with a percentage of $35 \%$.

\section{Normality test}

Normality test data used in this study using the Liliefors test with test criteria if the value of $\mathrm{L}$ count $<\mathrm{L}$ table, then the data is normally distributed. Based on the results of the ball dribbling ability test in soccer games in both the JIGSAW and TGT experimental groups with a significant level of 0.05 and a $95 \%$ confidence level, the $\mathrm{L}$ arithmetic value is smaller than $\mathrm{L}$ table, so it can be concluded that the data distribution for all variables is normal. The following are the results of the normality test of the data in the JIGSAW method experimental group and the Team Game Tournament method group, which are presented in the following table:

Table 3. Normality Test Results

\begin{tabular}{lccc}
\hline Data & Lcount & Ltable & Conclusion \\
\hline TGT Group Pre-Test Data & 0,1566 & 0,220 & Normal \\
\hline TGT Group Final Test Data & 0,1260 & 0,234 & Normal \\
\hline Group Pre-Test Data JIGSAW & 0,0760 & 0,258 & Normal \\
\hline Group Final Test Data JIGSAW & 0,1476 & 0,234 & Normal \\
\hline
\end{tabular}

From the table above, it can be seen that the initial test data for the jigsaw experimental group L count $0.0760<\mathrm{L}$ table 0.258 which means normally distributed, the final test data for the JIGSAW experimental group L count $0.0760<\mathrm{L}$ table 0.258 which means normally distributed, the initial test data for the experimental group Team Game Tournament L count $0.1566<\mathrm{L}$ table 0.220 which means normal distribution, final test data for the Team Game Tournament experimental group L count $0.1260<$ L table 0.234 which means normal distribution.

\section{Homogeneity Test}

Homogeneity test was conducted to see whether the two groups had the same variance. To find out which variables have the same variance, the test that is carried out is by comparing the largest variance and the smallest variance from each group so that the Fcount value is obtained with the test criteria if the Fcount < Ftable then the two data are homogeneous or come from the same variance. same. It turned out that the test results obtained Fcount < Ftable, then the two variances were homogeneous. The following are the results of the homogeneity test of the data in the experimental group 1, namely the jigsaw method and the experimental group 2, namely the team game tournament (TGT) method, are presented in the following table:

Table 4. Homogeneity Test Results

\begin{tabular}{|c|c|c|c|c|}
\hline Data & & Lcount & Ltable & Conclusion \\
\hline $\begin{array}{l}\text { Pre-Test Experimental } \\
J I G S A W\end{array}$ & Group $T G T$ dan & 2,058 & 3,59 & Homogeneous \\
\hline $\begin{array}{l}\text { Final Test Experimental } \\
\text { Tournament and } J I G S A W\end{array}$ & Group Team Game & 2,4165 & 3,59 & Homogeneous \\
\hline
\end{tabular}

From the table above, it can be seen that the results of the homogeneity test of the Initial Test of the jigsaw and TGT experimental groups were obtained, namely F count $2.058<\mathrm{F}$ table 3.59 which means the data is homogeneous, then for the Final Test of the Experimental Group Team Game Tournament (TGT) and jigsaw, namely obtained F count $2.4165<$ F table 3.59 which means the data is homogeneous. 


\section{The Effectiveness of Cooperative Learning Jigsaw Model and Team Game Tournament (TGT) on Dribling Ability in Football Games Class XI State High School 2 Gadingrejo}

\section{Hypothesis testing}

Hypothesis testing is basically a step to test whether the statements put forward in the formulation of the hypothesis can be accepted or rejected. The data obtained were then analyzed using t-test to test the hypotheses that have been compiled in the this research. The following is a t-test table for each data:

Table 5. T-test table

\begin{tabular}{lllc}
\hline Data & Lcount & Ltable & Conclusion \\
\hline Pre-test and post-test TGT group & 0,38 & 2.080 & Significant \\
\hline Jigsaw group pre-test and post-test & 6,041 & 2.080 & Significant \\
\hline
\end{tabular}

a.Analysis of Group Hypotheses of Team Game Learning Model Tournament After each group received treatment, then to prove the change a statistical calculation was carried out using the t-test formula. The results of the t-test calculation for the test initial and post-test in the TGT group obtained a count of $0.38>\mathrm{t}$ table 2.080 which means rejecting the null hypothesis (H0). So it can be concluded that there is a significant influence on the ability to dribble the ball with the TGT . learning model

b.JIGSAW Learning Model Group Hypothesis Analysis. After each group received treatment, then to prove the change a statistical calculation was carried out using the t-test formula. The results of the t-test calculation for the test the initial and final tests in the Jigsaw group obtained tcount $6.041<\mathrm{t}$ table 2.080 which means accept hypothesis two (H2). So it can be concluded that there is a significant influence on the ability to dribble the ball with the Jigsaw . learning model

5. Hypothesis Analysis of the influence between Learning Groups Jigsaw and TGT. Based on the results of calculations to find differences in the final test of the Jigsaw and TGT cooperative learning groups, the t-count value is 3.622 and the t-table value is at a significant level of 0.05 or at the $95 \%$ confidence level, the t-table is 1.721. If -ttable t count then $\mathrm{H} 3$ is accepted and $\mathrm{H} 0$ is rejected. Based on the results of the calculations carried out, the value of tcount is 3.622> ttable 1.721. This means that in the final test of the jigsaw and TGT groups there is a more significant difference in the class XI State High School 2 Gadingrejo.

\section{Different Test}

Table 6. Different Test

\begin{tabular}{ccc}
\hline Group name & tcount & table \\
\hline Group pre-test JIGSAW and TGT & 5.14 & 1,721 \\
\hline Group final test JIGSAW and TGT & 3.622 & 1,721 \\
\hline
\end{tabular}

From the results of the table above, in the initial test for the jigsaw and TGT groups, it was obtained that $\mathrm{t}$ count was $5.14>$ $\mathrm{t}$ table of 1.721, then rejected $\mathrm{H} 0$ and accepted $\mathrm{H} 1$ which means that there is a significant difference between the initial test of the TGT and JIGSAW learning models. In the final test of the jigsaw and TGT groups, the t count was $3.622>\mathrm{t}$ table 1.721 , so H0 was rejected and $\mathrm{H} 1$ was accepted, which means that there was a significant difference in the final test between the TGT and JIGSAW learning models.

\section{CONCLUSION}

1. Based on the results of testing the first hypothesis, it proves that there is a significant effect of ball dribbling exercises using the jigsaw cooperative learning model. Judging from its characteristics, dribbling the ball is one of the basic techniques that must be mastered well in the sport of football, because dribbling the ball is often used by football players in an effort to score points. Dribbling the ball serves to control the ball in outwit the opponent with the aim of scoring points into the opponent's goal in order to lead and win the match. With the jigsaw method, there was no significant increase in dribbling in football.

2. The results of testing the second hypothesis prove that there is a significant effect of dribbling the ball using the Team Game Tournament learning model. Based on the results of research and activities during the research on class XI students of SMA Negeri 2 Gading Rejo, it was seen that there was a significant increase in student achievement after being given dribbling training with the model. TGT is seen from some of the better dribbling abilities of the ball, which is faster than before being given treatment.

3. Meanwhile, the results of testing the third hypothesis prove that there is a significant effect of dribbling practice using the jigsaw and TGT learning models. From the results of the analysis for the use of the JIGSAW learning model and the Team 
The Effectiveness of Cooperative Learning Jigsaw Model and Team Game Tournament (TGT) on Dribling Ability in Football Games Class XI State High School 2 Gadingrejo

Game Tournament, the two learning models have a significant effect on the ball dribbling ability of the Class XI State High School 2 Gadingrejo. This effect can be seen in the increase in the average value of the results of the ball dribbling ability between students who use the JIGSAW learning model and the Team game Tournament learning model, so it can be concluded that the improvement in ball dribbling skills in soccer games using both models is very good.

\section{REFERENCES}

1. Avdeeva, M. S., \& Tulyakova, O. V. (2018). Indicated factors of physical development, physical readiness, functional condition and efficiency of female students in the process of adaptation to training. Physical Education of Students, 22(1), 4-10. https://doi.org/10.15561/20755279.2018.0101

2. Eryiğit, Ö., \& Ay, S. M. (2021). An Investigation of Physical Activity Levels of Academicians in Sport Science. European Journal of Physical Education and Sport Science, 6(10), 1-12. https://doi.org/10.46827/ejpe.v6i10.3497

3. Fudin, M. S., \& Hariyadi, K. (2020). Development of a Football Game Modification Book for Primary School Physical Education and Health Teachers. Journal of Physical Education, Sport, Health and Recreation, 9(3), 168-172.

4. Harvey, S., Kirk, D., \& O’Donovan, T. M. (2014). Sport Education as a pedagogical application for ethical development in physical education and youth sport. Sport, Education and Society. https://doi.org/10.1080/13573322.2011.624594

5. Hornig, M., Aust, F., \& Güllich, A. (2016). Practice and play in the development of German top-level professional football players. European Journal of Sport Science, 16(10), 96-105. https://doi.org/10.1080/17461391.2014.982204

6. Jian Andri Kurniawan, Hari Amirullah Rahman, \& Soegiyanto, K. S. (2015). Journal of Physical Education and Sports. $4(1), 8-13$.

7. Marwan, I. (2019). Model Physical Education using Modification of Mini Volley Ball Game to Improve Friendly Character at Elementary School. International Journal of Innovative Science and Research Technology, 4(5).

8. Minana-Signes, V., \& Monfort-Panego, M. (2021). The Conditioning of the Trunk Muscles and Back Health in Physical Education. Journal of Human Sport and Exercise, 16(3), 640-651. https://doi.org/10.14198/jhse.2021.163.13

9. Pasichnyk, V., Khimenes, K., Pityn, M., Bas, O., Hlukhov, I., Hnatchuk, Y., \& Drobot, K. (2021). Physical condition of preschool children with disabilities in psychological and physical development. Journal of Physical Education and Sport, 21(1), 352-359. https://doi.org/10.7752/jpes.2021.01033

10. Rafi, M., Nurhayati, T., \& Sari, D. M. (2018). Heart Rate Profile of Professional and Amateur Football Athletes in Bandung. Journal of Medicine \& Health, 2(2), 798-805. https://doi.org/10.28932/jmh.v2i2.1019

11. Ryom, K., Ravn, M., Düring, R., \& Henriksen, K. (2020). Talent Development in Football—A Holistic Perspective: The Case of KRC Genk. International Sport Coaching Journal, 7(9), 360-369. https://doi.org/10.1123/iscj.2019-0045

12. Sugiyama, M., Khoo, S., \& Hess, R. (2017). Grassroots football development in Japan. International Journal of the History of Sport, 34(17-18), 1854-1871. https://doi.org/10.1080/09523367.2017.1340881 